\title{
PENERAPAN FRAMEWORK MODEL-VIEW- CONTROLLER (MVC) PADA SISTEM INFORMASI MANAJEMEN DATA JEMAAT BERBASIS WEB (Studi kasus GKI Maranatha Kampung Harapan)
}

\author{
Erpina Desy Christina Sihombing ${ }^{1}$, Syari Rukmana Wahab ${ }^{2}$ \\ Manajemen Informatika ${ }^{1}$, Ilmu Komputer ${ }^{2}$ \\ Sekolah Tinggi Manajemen dan Ilmu Komputer Umel Mandiri ${ }^{1,2}$ \\ Email: erpinadcs@ stmikumelmandiri.ac.id ${ }^{1}$, \\ syarirukmana@stmikumelmandiri.ac.id ${ }^{2}$
}

\begin{abstract}
Abstrak: Gereja merupakan salah satu organisasi yang bergerak dalam pelayanan masyarakat. Gereja juga memiliki sistem informasi manajemen termasuk pengelolaan, penyimpanan, dan penyajian data. Data pertumbuhan jemaat pada GKI Maranatha Kampung Harapan-Asrama selama ini tersimpan dalam bentuk dokumen, sehingga menyebabkan kendala bagi sekretaris gereja untuk menyediakan informasi petumbuhan jemaat dan data-data anggota keluarga, baptis, sidi, pernikahan, kematian, kelahiran, status dalam jemaat dan kegiatan gereja. Sistem Informasi Manajemen Data Jemaat yang di bangun berbasis web dengan menerapkan Framework Model View Controler. Konsep Model View Contoller atau biasa disingkat dengan MVC merupakan sebuah arsitektur dimana proses pada sistem dipisah menjadi tiga bagian dengan tugas-tugas dan tanggungjawab masing-masing bagian. Penerapan konsep MVC pada sistem informasi data jemaat berbasis web diharapkan menghasilkan website yang lebih terstruktur dengan memisahkan data (model), tampilan (view) dan cara bagaimana memprosesnya (controller). Metode yang digunakan dalam pengembangan sistem ini dengan menggunakan metode Prototype. Di mana metode prototype melibatkan user secara langsung dengan analisis dan perancangan sistem, hal inisangat efektif untuk pengoreksian sistem. Sebagai hasil, sistem informasi yang dibangun akan menjadi alat bantu bagi sekretaris gereja dalam mengelola data jemaat dan menghasilkan informasi data jemaat yang akurat, up to date (mutakhir), aman dan tersedia bagi pengguna (user).
\end{abstract}

Kata kunci: Gereja; Sistem Informasi; Model-View-Controler; Prototype.

\section{PENDAHULUAN}

Sistem informasi dapat membantu dan mendukung kinerja suatu instansi atau organisasi dalam pengolahan data untuk menghasilkan informasi yang relevan, akurat dan berguna. Teknologi telah berkembang terus-menerus dalam banyak aspek kehidupan manusia, salah satunya ada dalam praktek keagamaan. Selama beberapa tahun terakhir, pemanfaatan teknologi informasi untuk komunikasi di Gereja juga berkembang[1], [2]. Gereja merupakan salah satu organisasi yang bergerak dalam pelayanan masyarakat. Gereja juga memiliki sistem manajemen informasi termasuk pengelolaan, penyimpanan, dan penyajian data [3].

Gereja Kristen Injili (GKI) Maranatha Kampung Harapan-Asrama merupakan salah satu Gereja yang ada di Tanah Papua. Secara umum jemaat adalah GKI Maranatha Kampung Harapan-Asrama adalah jemaat yang majemuk, disebabkan karena GKI di Tanah Papua adalah suatu gereja yang bersifat oikumenis, dan bukan gereja suku. Selama 56 tahun berdiri, anggota jemaat terus berkembang dan kini sudah mencapai 684 anggota jemaat terdiri dari $146 \mathrm{KK}$ (kepala keluarga) yang di bagi menjadi 3 (tiga) Wyk dan 8 (delapan) Kelompok Sel Pemuridan (KSP).Data pertumbuhan jemaat pada GKI Maranatha Kampung Harapan-Asrama

Ciptaan disebarluaskan di bawah Lisensi Creative Commons Atribusi 4.0 Internasional. 
selama ini tersimpan dalam bentuk dokumen di Ms. Office Word, sehingga menyebabkan kendala bagi sekretaris gereja untuk menyediakan informasi petumbuhan jemaat dan data-data anggota keluarga yang terdiri dari data baptis, sidi, pernikahan, kematian, kelahiran, status dalam jemaat dan kegiatan gereja. Selain itu setiap minggu pada warta jemaat di beri ucapan selamat ulang tahun bagi jemaat yang berulang tahun tuliskan anggota jemaat yang berulang tahun karena tidak tersedia data tersebut.

Permasalahan yang ada pada GKI Maranatha Kampung Harapan adalah pada manajemen data jemaat, maka diperlukan suatu sistem informasi majemen data jemaat supaya gereja dapat memiliki data jemaat yang akurat, up to date (mutakhir), aman dan tersedia bagi pengguna (user). Sistem Informasi Manajemen Data Jemaat yang di bangun berbasis web dengan menerapkan Framework Model View Controler. Konsep Model View Contoller atau biasa disingkat dengan MVC merupakan sebuah arsitektur dimana proses pada sistem dipisah menjadi tiga bagian dengan tugas-tugas dan tanggungjawab masing-masing bagian. Konsep ini lebih memudahkan programmer dalam mengatur query database, manajemen kode, validasi data dan keamanan [4]. Website dengan menggunakan pola Model-View-Controller (MVC), memberikan kualitas proses pembangunan dan akses pengelolaan sumber daya informasi [5]. MVC membantu mengurangi kompleksitas dari pembuatan desain dan menambah fleksibilitas dan pemakaian kembali (re-use) kode [6]. Penerapan konsep MVC pada sistem informasi data jemaat berbasis web diharapkan dapat memberikan solusi permasalahan yang ada pada GKI Maranatha saat ini.

\section{METODE DAN MATERI \\ 2.1 METODE}

\section{Metode Pengembangan Sistem}

Metode yang digunakan dalam pengembangan sistem ini dengan menggunakan metode Prototype. Di mana metode prototype melibatkan user secara langsung dengan analisis dan perancangan sistem, hal ini sangat efektif untuk pengoreksian sistem. Dengan metode Prototype ini pengembang dan pengguna dapat saling berinteraksi selama proses pembuatan sistem. [7]

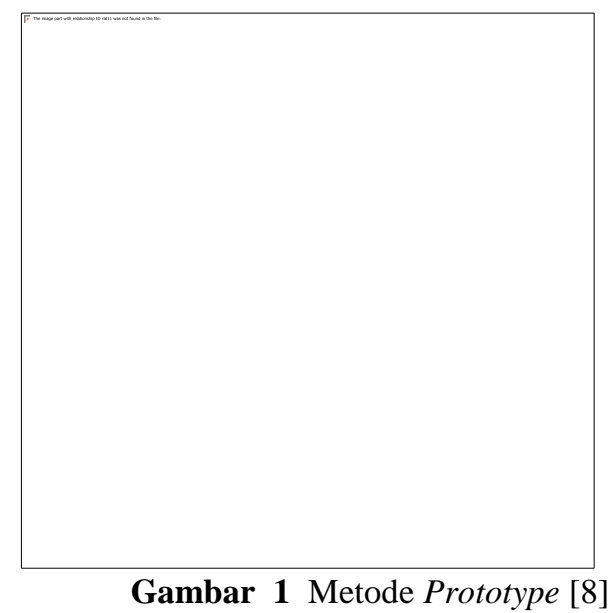

Berikut adalah tahapan dalam metode prototype :

1. Komunikasi dan pengumpulan data awal, yaitu analisis terhadap kebutuhan pengguna.

2. Quick design (desain cepat), yaitu pembuatan desain secara umum untuk selanjutnya dikembangkan kembali.

3. Pembentukan prototype, yaitu pembuatan perangkat prototype termasuk pengujian dan penyempurnaan.

4. Evaluasi terhadap prototype, yaitu mengevaluasi prototype dan memperhalus analisis terhadap kebutuhan pengguna. 
5. Perbaikan prototype, yaitu pembuatan tipe yang sebenarnya berdasarkan hasil dari evaluasi prototype.

6. Produksi akhir, yaitu memproduksi perangkat secara benar sehingga dapat digunakan oleh pengguna.

\subsection{MATERI}

Penelitian yang terkait Yuliawan, dkk. mengembangkan Sistem Informasi Pendataan Jemaat Gereja Berbasis Web. Website ini dapat menghasilkan laporan yang dibutuhkan oleh admin gereja dan konferens dalam mengetahui perkembangan jemaat seperti, jumlah jemaat pada tiap gereja, jumlah pertambahan jemaat, jumlah baptisan, jumlah kelas sekolah sabat, jumlah jemat yang menikah dan belum menikah, jumlah penghasilan jemaat pada masing-masing gereja, jumlah perpindahan, dan jumlah kematian[9]. Manulangga dan Sara mengembangkan Sistem Informasi Penatalayanan Jemaat Gereja Berbasis Web. Dalam sistem informasi ini menampilkan data jemaat, data keluarga, data majelis, data anggota organisasi, data ibadah_lingkungan, data ibadah_minggu yang di tampilkan sebagai informasi untuk jemaat dan laporan kepada pihak sekretariat gereja[10].

Rupilele merancang Sistem Informasi Manajemen Pelayanan Anggota Jemaat, Baptisan, Dan Pernikahan Berbasis Web. Hasil perancangan sistem dalam penelitian ini menampilkan informasi tentang gereja dan perangkat pelayan, informasi kegiatan gereja, warta jemaat, artikel, pelayanan pendaftaran anggota jemaat, baptisan dan pernikahan, laporan data pendaftaran yang sajikan dalam bentuk grafik, laporan cetakan surat baptis dan surat nikah serta manajemen seluruh data jemaat dan data gereja[3].

Perbedaan dengan penelitian sebelumnya adalah Sistem Informasi Manajemen Pendataan Jemaat ini di bangun berbasis web dengan menerapkan framework Model-View-Controler Model View Controler. Konsep Model View Contoller atau biasa disingkat dengan MVC merupakan sebuah arsitektur dimana proses pada sistem dipisah menjadi tiga bagian dengan tugas-tugas dan tanggungjawab masing-masing bagian. Konsep ini lebih memudahkan programmer dalam mengatur query database, manajemen kode, validasi data dan keamanan [4]. Website dengan menggunakan pola Model-View-Controller (MVC), memberikan kualitas proses pembangunan dan akses pengelolaan sumber daya informasi [5]. MVC membantu mengurangi kompleksitas dari pembuatan desain dan menambah fleksibilitas dan pemakaian kembali (re-use) kode [6]. Penerapan konsep MVC pada sistem informasi data jemaat berbasis web diharapkan menghasilkan website yang lebih terstruktur dengan memisahkan data (model), tampilan (view) dan cara bagaimana memprosesnya (controller).

\subsubsection{Framework Model-View-Controller (MVC)}

Model-View-Controller (MVC) adalah sebuah konsep yang diperkenalkan oleh penemu Smalltalk (Trygve Reenskaug) untuk meng-enkapsulasi data bersama dengan pemrosesan (model), mengisolasi dari proses manipulasi (controller) dan tampilan (view) untuk direpresentasikan pada sebuah user interface. MVC merupakan suatu konsep yang cukup popular dalam pembangunan aplikasi web. MVC memisahkan pengembangan aplikasi berdasarkan komponen utama yang membangun sebuah aplikasi seperti manipulasi data, user interface, dan bagian yang menjadi control aplikasi [11]

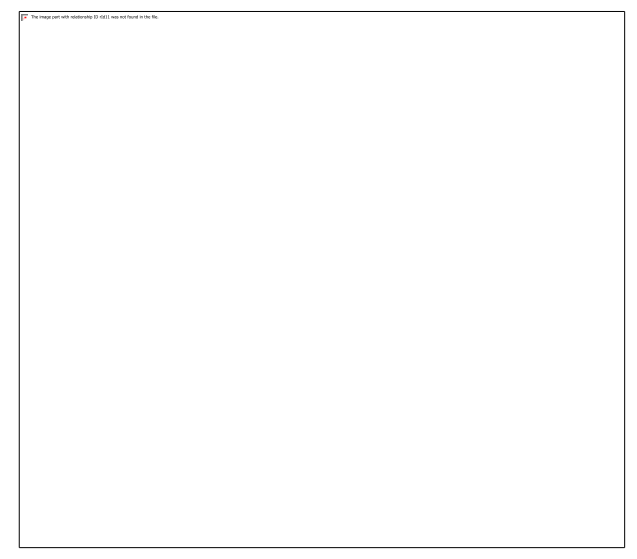

Gambar 2. Cara Kerja MVC [11]

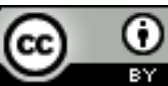

Ciptaan disebarluaskan di bawah Lisensi Creative Commons Atribusi 4.0 Internasional. 
Terdapat 3 jenis komponen yang membangun suatu MVC pattern dalam suatu aplikasi yaitu [11]:

1. View, merupakan bagian yang menangani presentation logic. Pada suatu aplikasi web bagian ini biasanya berupa file template HTML, yang diatur oleh controller. View berfungsi untuk menerima dan mempresentasikan data kepada user. Bagian ini tidak memiliki akses langsung terhadap bagian model.

2 Model, biasanya berhubungan langsung dengan database untuk memanipulasi data (insert, update, delete, search), menangani validasi dari bagian controller, namun tidak dapat berhubungan langsung dengan view.

3. Controller, merupakan bagian yang mengatur hubungan antara bagian model dan bagian view, controller berfungsi untuk menerima request dan data dari user kemudian menentukan apa yang akan diproses oleh aplikasi.

\subsubsection{Sistem Informasi Manajemen}

Sistem informasi manajemen (SIM) atau management information system (MIS) adalah sistem informasi yang digunakan untuk menyajikan informasi yang digunakan untuk mendukung operasi, manajemen, dan pengambilan keputusan dalam suatu organisasi. Bentuk umum SIM diperlihatkan di Gambar 2. [12]

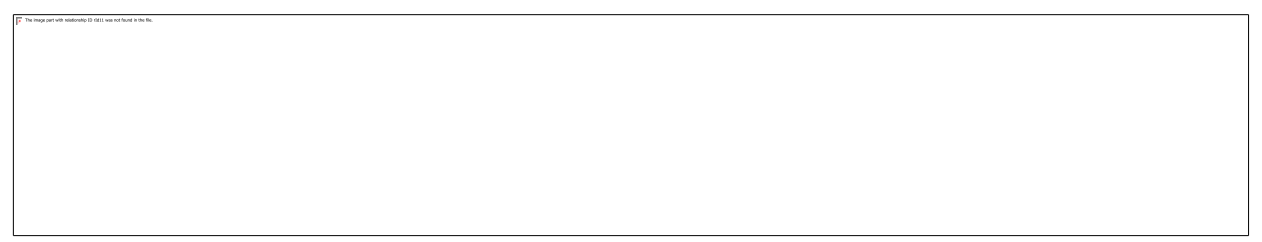

Gambar 3. Sistem Informasi Manajemen [12]

Suatu SIM adalah kumpulan dari manusia dan sumber-sumber daya modal di dalam suatu organisasi yang bertanggung-jawab mengumpulkan dan mengolah data untuk menghasilkan informasi yang berguna untuk semua tingkatan manajemen di dalam kegiatan perencanaan dan pengendalian [13].

Kegiatan manajemen di Gereja umumnya meliputi: 1) Pendataan jemaat yang mencatat informasi tentang petumbuhan jemaat dan data-data anggota keluarga, atestasi, baptis, sidi, pernikahan, kematian, kelahiran, status dalam jemaat dan kegiatan gereja; 2) Jadwal kegiatan gereja yang meliputi kegiatan ibadah dan kegiatan-kegiatan pendukung gereja.

\subsubsection{Data Jemaat}

Data atau fakta adalah kenyataan dari suatu kejadian atau peristiwa. Data organisasi merupakan hasil kegiatan dari organisasi tersebut. Dalam konteks sistem informasi data dipandangan sebagai keterangan yang masih mentah. Data yang sudah diolah sesuai dengan keperluan disebut sebagai informasi. Pengolahan data menjadi informasi dapat dilakukan dengan alat pengolah manual maupun computer [14].

Gereja merupakan salah satu organisasi yang bergerak dalam pelayanan masyarakat. Gereja juga memiliki sistem manajemen informasi termasuk pengelolaan, penyimpanan, dan penyajian data [3]. Anggota organisasi Gereja disebut jemaat yaitu suatu perkumpulan terdiri dari orang-orang beriman yang berbakti kepada Tuhan. Maka data jemaat adalah data organisasi gereja dari hasil kegiatan gereja meliputi Pembaptisan, Sidi, Pernikahan, Ibadah, Kelahiran, Kematian dan Status Jemaat. 


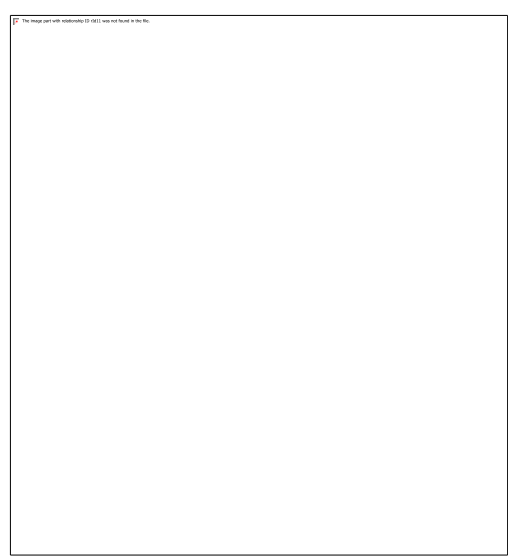

Gambar 4. Hubungan fakta, data, arsip dan informasi [14]

Pendataan merupakan suatu proses pencatatan keterangan yang benar dan nyata tentang sesuatu, baik manusia, benda, lingkingan, maupun kejadian tertentu. Pencatatan ini dimaksudkan sebagai suatu dokumentasi atau arsip yang dapat digunakan untuk suatu keperluan di masa depan. Adapun keperluan utama dari suatu pendataan adalah pembuatan laporan. Pembuatan laporan dimaksudkan sebagai dasar atau bahan informasi untuk pertimbangan bagi pemimpin organisasi/perusahaan untuk mengambil suatu keputusan [15].

\subsection{PERANCANGAN SISTEM}

\section{a. Use Case Diagram}

Perancangan sistem informasi administrasi Manajemen data jemaatn ini dirancang menggunakan Unified Modelling Language (UML). UML menyediakan beberapa diagram dalam proses perancangan sistem. Use case diagram menggambarkan apa yang dapat dilakukan aktor terhadap sistem yang akan dibangun. Use case diagram terdiri dari aktor, use case dan hubungannya.

Gambar 5 Use Case Diagram 
Pada Gambar 5 dapat dijelaskan bahwa dalam sistem yang akan dibangun hanya terdapat dua aktor yaitu admin (sekretaris jemaat) dan user yaitu Pendeta, Majelis, Jemaat dan umum. Admin memiliki hak akses penuh ke dalam sistem, yang terdiri dari login, manajemen data jemaat, Data Wyk, Data KSP, Data Kelahiran, Data Baptis, Data Sidi, Data Pernikahan, Data Kematian dan Data Anggota Keluar (Mutasi).

\section{b. Desain User Interface}

User Interface adalah tampilan visual sebuah produk yang menjembatani sistem dengan pengguna (user). Tampilan UI dapat berupa bentuk, warna, dan tulisan yang didesain semenarik mungkin. Secara sederhana, UI adalah bagaimana tampilan sebuah produk dilihat oleh pengguna. Gambar 6 merupakan desain User Interface pada manajemen data Anggota, terdapat data diri, data penunjang, data baptis, data sidi dan data nikah.

Gambar 6 Desain User Interface

\section{PEMBAHASAN DAN HASIL}

\subsection{Implementasi Sistem}

Sistem Informasi Manajemen Data Jemaat GKI Maranatha Kampung Harapan Asrama dibangun dengan menerapkan Framework Model-View-Controller (MVC). MVC merupakan suatu konsep yang cukup popular dalam pembangunan aplikasi web. MVC memisahkan pengembangan aplikasi berdasarkan komponen utama yang membangun sebuah aplikasi seperti manipulasi data, user interface, dan bagian yang menjadi control aplikasi [11] Terdapat 3 jenis komponen yang membangun suatu MVC dalam Sistem Informasi Manajemen Data Jemaat GKI Maranatha Kampung Harapan Asrama yaitu: 1. Komponen View, terdiri dari profil gereja, 
galeri gereja, tambah anggota, data wyk, data KSP, data baptis, data sidi, data pernikahan, data kematian, dan data anggota keluar. 2. Komponen Model, biasanya berhubungan langsung dengan database untuk memanipulasi data (insert, update, delete, search), menangani validasi dari bagian controller, namun tidak dapat berhubungan langsung dengan view. 3. Controller, merupakan bagian yang mengatur hubungan antara bagian model dan bagian view, controller berfungsi untuk menerima request dan data dari user kemudian menentukan apa yang akan diproses oleh aplikasi. Sebelum admin atau sekretaris gereja dapat mengolah data jemaat, terlebih dahulu harus melakukan login ke dalam sistem Informasi Manajemen Data Jemaat GKI Maranatha Kampung Harapan Asrama dengan memasukan email dan password, seperti yang ditunjukan pada gambar 7 .

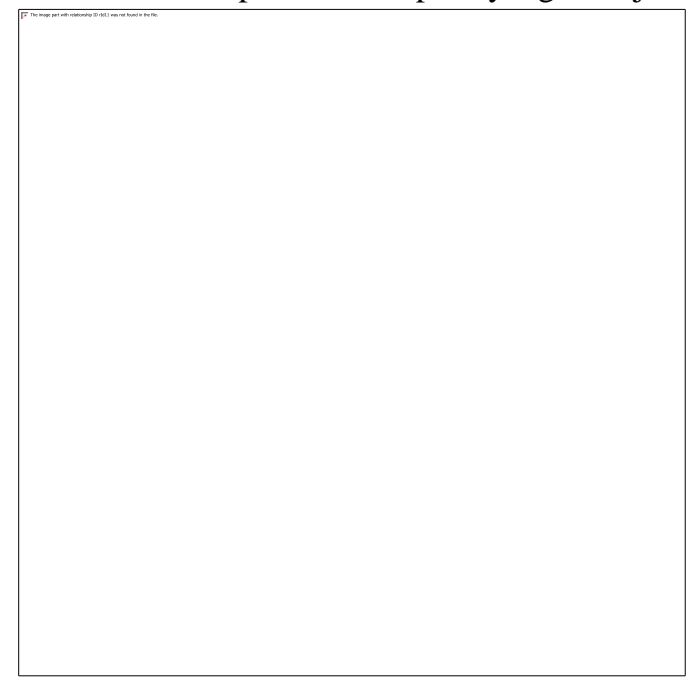

Gambar 7 Menu Login Admin

Setelah admin berhasil login ke dalam sistem, maka terdapat menu manajemen data jemaat yang dapat dikelolah oleh admin seperti yang ditunjukan pada Gambar 8. Pada menu manajemen data jemaat teridiri dari tambah anggota, data wyk, data KSP, data baptis, data sidi, data pernikahan, data kematian, data anggota keluar (mutasi) dan laporan.

Gambar 8 Tampilan Menu Admin 
Gambar 9 merupakan tampilan dari menu tambah data anggota. Admin yang merupakan sekretaris gereja dapat melakukan manajemen data jemaat, salah satunya adalah menambahkan anggota jemaat baru. Pada menu tambah anggota terdapat beberapa data yang harus diinputkan yaitu data diri, data pelengkap, data baptis, data sidi dan data pernikahan. Dengan adanya sistem informasi manajemen data jemaat berbasis web membantu sekretaris jemaat dalam mengelola data jemaat dan menghasilkan informasi data jemaat yang akurat, up to date (mutakhir), aman dan tersedia bagi pengguna (user).

Gambar 9 Tampilan Data Anggota

\section{KESIMPULAN}

Penerapan MVC dapat menghasikan website sistem informasi manajemen data jemaat, dimana sekretaris jemaat sebagai admin dapat dapat mengelola data anggota jemaat yang terdiri dari $146 \mathrm{KK}$ (kepala keluarga) yang di bagi menjadi 3 (tiga) Wyk dan 8 (delapan) Kelompok Sel Pemuridan (KSP). Dengan adanya sistem informasi manajemen data jemaat berbasis web membantu sekretaris jemaat dalam mengelola data jemaat dan menghasilkan informasi data jemaat yang akurat, up to date (mutakhir), aman dan tersedia bagi pengguna (user).

\section{REFERENASI}

[1] Bolu, Christian A. (2012) "The church in the contemporary world: Information and communication technology in church communication for growth: A case study" Journal of Media and Communication Studies Vol. 4(4), pp. 80-94, April 2012.

[2] Kurniawan, Y., \& Cassandra, C. (2014) "Development of church information system (A case study approach" International Journal of Software Engineering and Its Applications, vol.8. no.12, 199-208.

[3] Rupilele, Frits Gerit John (2018) "Perancangan Sistem Informasi Manajemen Pelayanan Anggota Jemaat, Baptisan, Dan Pernikahan Berbasis Web (Studi Kasus: Gekari Lembah Pujian Kota Sorong)” Jurnal Teknologi Informasi dan Ilmu Komputer (JTIIK) Vol. 5, No. 2, Mei 2018, hlm. 147-156.

[4] Suendri (2018) "Penerapan Konsep Model View Controller Pada Perancangan Sistem Manajemen Software Berbasis Web" JISTech, Vol.3, No.2, Juli - Desember 2018.

\footnotetext{
Ciptaan disebarluaskan di bawah Lisensi Creative Commons Atribusi 4.0 Internasional.
} 


\section{Journal of Information System, Applied, Management, Accounting and Research.}

http://journal.stmikjayakarta.ac.id/index.php/jisamar, jisamar@stmikjayakarta.ac.id, jisamar2017@gmail.com e-ISSN: 2598-8719 (Online), p-ISSN: 2598-800 ( Printed), Vol. 5 No.1 Februari 2021

[5] Sanjaya, Rangga (2016) "Perancangan Sistem Informasi Manajemen Perpustakaan Menggunakan Pola Model-View-Controller (MVC)” Jurnal Informatika. 2. 10.31311/ji.v2i1.87.

[6] Cui, Wei., Huang, Lin., Liang, Lijing., \& Li, Jing. (2009) "The Research of PHP Development Framework Based on MVC Pattern" Fourth International Conference on Computer Sciences and Convergence Information Technology (ICCIT), pp.947-949.

[7] Amsyah, Zulkifli. 2005. Manajemen Sistem Informasi. Jakarta: Gramedia Pustaka Utama.

[8] Pressman, Roger S. 2012. Rekayasa Perangkat Lunak. Yogyakarta: Andi.

[9] Yuliawan, Yeremia, M.J. Dewiyani Sunarto \& Tony Soebijono. 2013. Pengembangan Sistem Informasi Pendataan Jemaat Gereja Masehi Advent Hari Ketujuh Konferens Jawa Kawasan Timur Berbasis Web. Jurnal Sistem Informasi : JSIKA Vol 2, No 2 (2013)/ISSN 2338-137X.

[10] Manulangga, Gloria \& Sara Gultom. 2016. Sistem Informasi Penatalayanan Jemaat Gereja HKBP Kupang Berbasis Web. Jurnal Ilmiah FLASH Volume 2 Nomor 2 Desember 2016.

[11] Putratama, Supono Virdiandry. 2016. Pemrograman Web dengan Menggunakan PHP dan Framework Codeigniter. Yogyakarta: deepublish.

[12] Kadir A., 2014. Pengenalan Sistem Informasi Edisi Revisi, Yogyakarta: Andi.

[13] Jogiyanto HM., 2005. Analisis dan Desain Sistem Informasi: Pendekatan Terstruktur Teori dan Praktik Aplikasi Bisnis. Yogyakarta: Andi.

[14] Amsyah, Zulkifli. 2005. Manajemen Sistem Informasi. Jakarta: Gramedia Pustaka Utama.

[15] Herlambang, S. 2005. Sistem Manajemen Basis Data: Pemodelan Sistem. Yogyakarta: Graha Ilmu. 